\title{
APPLIED TOOLS FOR INTELLECTUAL CAPITAL FORMATION IN THE CONTEXT OF SOCIO-POLITICAL TRANSFORMATIONS
}

\section{ПРИКЛАДНИЙ ІНСТРУМЕНТАРІЙ ФОРМУВАННЯ ІНТЕЛЕКТУАЛЬНОГО КАПІТАЛУ В УМОВАХ СУСПІЛЬНО-ПОЛІТИЧНИХ ТРАНСФОРМАЦЙ}

\author{
Tatiana Yu. Solomko \\ tatyana-solomko@ukr.net \\ ORCID: 0000-0002-3029-7920 \\ Tatiana V. Baulina \\ tanyabaulina@gmail.com \\ ORCID: 0000-0002-0110-849X \\ Tamara V. Kuchtyk \\ ditmtvk@icloud.com \\ ORCID: 0000-0002-2000-3669
}

\author{
Т. Ю. Соломко, \\ канд. техн. наук, доцент
}

Т. В. Бауліна,

д-р екон. наук, професор

Т. В. Кухтик,

д-р техн. наук, професор, ректор

\author{
Donbass Institute of Technology and Management of \\ Academician Yuriy Bugay International Scientific and Technical University, Kramatorsk \\ Донбаський інститут техніки та менеджменту \\ Міжнародного науково-технічного університету імені академіка Юрія Бугая, м. Краматорськ
}

\begin{abstract}
The goal of the article is development and justification of theoretical and methodological principles, methodological foundations and practical recommendations on the implementation of the state policy in the sphere of intellectual capital formation and development to enhance the processes of the national economy modernization and innovative intellectual sphere development in Ukraine, development of an algorithm to systematize and generalize the significant body of information for the accumulation and transformation of knowledge about changes in the systemuniversal functioning capabilities development.

Method. The development of applied tools for implementing objective procedures for assessing and predicting intellectual capital parametric changes and developing a strategy for its formation in the context of national economy modernization, which is implemented by using analysis and generalization methods.

Results. Outlining the historical determinism, formation and growth general patterns, trends and features and the national economy intellectual capital use processes, the authors: 1) identified the state mechanisms for intensifying these processes by experimentally checking their adequacy and building forecasts of macroeconomic indicators based on the developed program "MainStreaM.For. IC v.6.3"; 2) specified the constitutive-key factors for ensuring the effectiveness of strategic management technologies; 3) characterized modern policy transformation determinants for intellectual capital formation within the complex state economic system.

Practical importance. Practical recommendations are presented to solve classification and information database ranking problems, forecasting and optimization of forming intellectual capital procedure to determine the composition of adaptive technologies for managing and regulating the economy.

The results of forecasting and analytical assessment of the main macroeconomic indicators and resource provision of scientific and technical progress in the state, set the complexity of the modern historical stage of the national economy development in the condition of absence of adequate real socio-economic processes of resource-functional ensuring the cognitive-informational aspects of the movement in translation of negative resonance events due to simultaneous progress and materialization of negative economic phenomena, namely:

1) inertial and destructive influence of public administration entities on the system-forming regulators of the national economy;

2) general system of strategic management deformation of formation, building and rational processes and effective use of existing intellectual potential;

3) economic priorities permanent search and change in the absence of specific in accordance with national interests, target functions that will link the goals with the means to achieve them.
\end{abstract}

Key words: intellectual capital; intellectual capital accumulation; national economy; production factors; intellectual investment; intellectual product. 
Анотація. Мета статmі - розробка і обгрунтування теоретико-методологічних засад, методичних основ i практичних рекомендацій щодо реалізації державної політики у сфері формування та становлення інтелектуального капіталу для активізації процесів модернізації національного господарства, а також розвитку інноваційно-інтелектуальної сфери в Україні, розробка алгоритму систематизації та узагальнення значного масиву інформації для накопичення і трансформації знань щодо змін параметрів розвитку потенціалів системно-універсального функціонування.

Методика. Розробка прикладного інструментарію для впровадження об’єктивних процедур для оцінюванняпрогнозування параметричних змін інтелектуального капіталу і розробки стратегії його формування в контексті модернізації національного господарства була реалізована за допомогою методів аналізу і узагальнення.

Результати. Окреслюючи історичну детермінованість, загальні закономірності, тенденції та особливості процесів формування, нарощення та використання інтелектуального капіталу національного господарства автори: 1) окреслили державні механізми інтенсифікації зазначених процесів за рахунок експериментальної перевірки їх адекватності та побудови прогнозів макроекономічних показників на основі розробленої програми "MainStreaM.For.IC v.6.3"; 2) конкретизували конститутивно-ключові чинники забезпечення дієвості технологій стратегічного управління; 3) охарактеризували детермінанти трансформації сучасної політики формування інтелектуального капіталу в межах складної економічної системи держави.

Практична значимість. Наведені практичні рекомендації дозволяють вирішувати проблеми класифікації та ранжування інформаційної бази даних, прогнозування і оптимізації процедури формування інтелектуального капіталу для визначення складу адаптивних технологій управління та регулювання економіки.

За результатами прогнозно-аналітичної оцінки основних макроекономічних показників і ресурсного забезпечення науково-технічного прогресу в державі встановлено складність сучасного історичного етапу розвитку національної економіки, яка полягає у відсутності адекватного реальним соціально-економічним процесам ресурсно-функціонального забезпечення когнітивно-інформаційних аспектів руху в умовах трансляції негативного резонансу подій, зумовлених синхронним перебігом і матеріалізацією таких негативних економічних явищ: 1) інерційно-деструктивного впливу суб'єктів державного управління на системоутворюючі регулятори національної економіки;

2) деформації загальної системи стратегічного управління процесами формування, нарощення та раціонального й ефективного використання існуючого інтелектуального потенціалу;

3) перманентного пошуку та зміни економічних пріоритетів за відсутності визначених відповідно до національних інтересів цільових функціоналів, які пов’язують такі цілі із засобами їх досягнення.

Ключові слова: інтелектуальний капітал; нагромадження інтелектуального капіталу; національне господарство; фактори виробництва; інтелектуальні інвестиції; інтелектуальний продукт.

\section{ПОСТАНОВКА ЗАДАЧІ}

Необхідно визнати, що сучасний етап розвитку суспільства характеризується надшвидким і безпрецедентним розвитком процесів глобалізації, основою для яких $є$ інноваційні та інформаційні ресурси. В таких умовах матеріальні знання та інформація стали невід'ємною частиною основного та інтелектуального капіталу. Соціально-економічні трансформації, які відбуваються у нашій державі, вимагають відпрацьованих технологій управління та нарощення інтелектуального капіталу. Нагромадження та застосування інноваційних знань набуло вирішального значення як інтелектуального чинника формування нового типу виробництва.

\section{АНАЛІЗ ОСТАННІХ ДОСЛІДЖЕНЬ І ПУБЛІКАЦІЙ}

Розробці теоретико-концептуальних підходів до державного управління у сфері нагромадження інтелектуального капіталу присвячено чимало праць зарубіжних і вітчизняних учених: О. Алимова, Д. Белла, Дж. Гелбрейта, Б. Данилишина, Л. Діккенса, Л. Едвідсона, М. Мелоуна, Т. Стюарта, Б. Андруш- ківа, О. Бутнік-Сіверського, Б. Малицького, І. Бистрякова, В. Геєця, Ю. Лисенка, О. Ляпунова, В. Микитенко, О. Новікової, Г. Савіної, О. Цибульова, А. Чухно, С. Шкарлета, Я. Яцкова.

\section{ВІДОКРЕМЛЕННЯ НЕ ВИРІШЕНИХ РАНІШЕ ЧАСТИН ЗАГАЛЬНОЇ ПРОБЛЕМИ}

Віддаючи належне науковому здобутку згаданих авторів, необхідно констатувати, що їхні праці остаточно не вирішили питання обгрунтування інтегрального напряму формування державної політики у сфеpi нагромадження інтелектуального капіталу, його складників та умов реалізації у процесі модернізації національного господарства.

Зазначене вище і зумовило нагальну необхідність у розробці структурованої та послідовної державної політики становлення та нагромадження інтелектуального капіталу національного господарства. Його використання у моделі інноваційного розвитку України вимагає вирішення проблеми вдосконалення інституціональних, управлінських та інформаційних державних структур, що й зумовило актуальність проведеного дослідження. Лише загальнонаціональ- 


\section{КОМП'ЮТЕРНІ НАУКИ ТА ІНФОРМАЦІЙНІ ТЕХНОЛОГІЇ № 4ロ 2020}

на консолідація інтелектуального капіталу та його ефективне використання є реальним підгрунтям для успішної реалізації національних економічних інтересів в Україні.

\section{МЕТА ДОСЛІДЖЕННЯ}

Метою дослідження $є$ розробка прикладного інструментарію щодо систематизації та узагальнення значного масиву інформації для накопичення і трансформації знань щодо змін параметрів розвитку потенціалів системно-універсального функціонування.

\section{МЕТОДИ, ОБ'ЄКТ ТА ПРЕДМЕТ ДОСЛІДЖЕННЯ}

Розробка прикладного інструментарію для провадження об'єктивних процедур щодо оцінюванняпрогнозування параметричних змін інтелектуального капіталу і розробки стратегії його формування в контексті модернізації національного господарства реалізується за допомогою методів аналізу і узагальнення.

Об'єктом дослідження $є$ інтелектуальний капітал не лише як засіб нарощення загального капіталу, а й як адекватне відображення дійсності та визначення пріоритетних напрямів трансформації національного господарства.

Предметом дослідження $є$ методичні аспекти формування державної політики у сфері нагромадження інтелектуального капіталу, його складників та умов реалізації під час процесу модернізації національного господарства.

\section{ОСНОВНИЙ МАТЕРІАЛ}

Для визначення складників і природи державної політики формування інтелектуального капіталу (далі - ДП господарства пріоритетом стає (як попередньо було визначено й обгрунтовано авторами у наукових працях [1, 2-4]) провадження процедур із комплексної діагностики структурно-динамічних характеристик розвиненості ІК. При оцінці процесів становлення та нагромадження інтелектуального капіталу як нематеріальної цінності національного господарства важливим $є$ не лише провадження процедур діагностики його приросту, а й отримання, систематизація та узагальнення значного масиву інформації для накопичення і трансформації знань щодо змін параметрів розвитку потенціалів системно-універсального функціонування.

Це зумовило необхідність формування і акумулювання когнітивно-інформаційних аспектів руху інтелектуального потенціалу національного господарства в контексті його модернізації. Зауважимо, що необхідність опрацювання великих масивів вхідної інформації, які постійно збільшуються, безпосередньо пов'язана 3 перевантаженнями допоміжними функціями апарату управління і державного регулю- вання. Це призводить до зниження якості функціонування суб'єктів управління на етапах стратегічного планування, оперативного керівництва, обліку, контролювання та аналізу і не дозволяє встановити об'єктивність існуючих умов провадження модернізації національного господарства та порогові значення відхилень для обгрунтування природи і цільових орієнтирів політики модернізації.

Як зазначалося у наукових працях [5-6] одним iз найбільш ефективних шляхів зниження такої відносної та абсолютної перевантаженості й дефіциту ресурсів опрацювання інформації $\epsilon$ застосування інформаційно-прикладних систем обробки даних. У зв'язку з цим автор вважає за доцільне обгрунтувати й запропонувати оптимальну архітектуру цільового програмного забезпечення, яка відповідає положенням, визначеним авторами в оригінальній інтегрованій концепції ідентифікації та формування інтелектуального капіталу національного господарства. Вони дозволяють скоротити терміни опрацювання вхідної інформації, якісно іiі перетворити, а також підвищити ефективність використання трудових ресурсів.

3 урахуванням цих позицій було розроблено базові положення та методологічні засади макроекономічного регулювання процесів забезпечення ефективності використання інтелектуального капіталу й запропоновано цільовий програмний продукт “MainStreaM.For.IC v.6.3” (рис. 1) [5]. Ці розробки $\epsilon$ спробою використати прикладний інструментарій для провадження об'єктивних процедур щодо оцінювання-прогнозування параметричних змін інтелектуального капіталу і розробки стратегії його формування в контексті модернізації національного господарства [6].

Вважаємо, що насамперед необхідно викласти авторську домінанту та погляд на опрацьовані в межax досліджень [7; 8] базові положення принципових методологічних підходів щодо стратегічного ресурсу модернізації економічної системи в державі. Розробка світоглядно-методологічного аспекту вирішення проблем реалізації політики формування інтелектуального капіталу вимагає застосування інформаційних технологій при моделюванні динаміки та обчисленні параметрів модернізації національного господарства. Ї̈̈ використання дозволяє об'єднати кілька робочих діагностичних процедур в одну, прискорюючи в кілька разів економетричний аналіз результатів і скорочуючи терміни як розроблення прогнозу економічних показників на різні терміни упередження, так і відповідної ресурсно-функціональної стратегії розвитку української економіки на засадах реалізації концепції формування та нагромадження інтелектуального капіталу.

Необхідно визнати, що впровадження оригінального пакету "MainStreaM.For.IC v.6.3" одночасно 3 проведенням модернізації та реструктуризації 


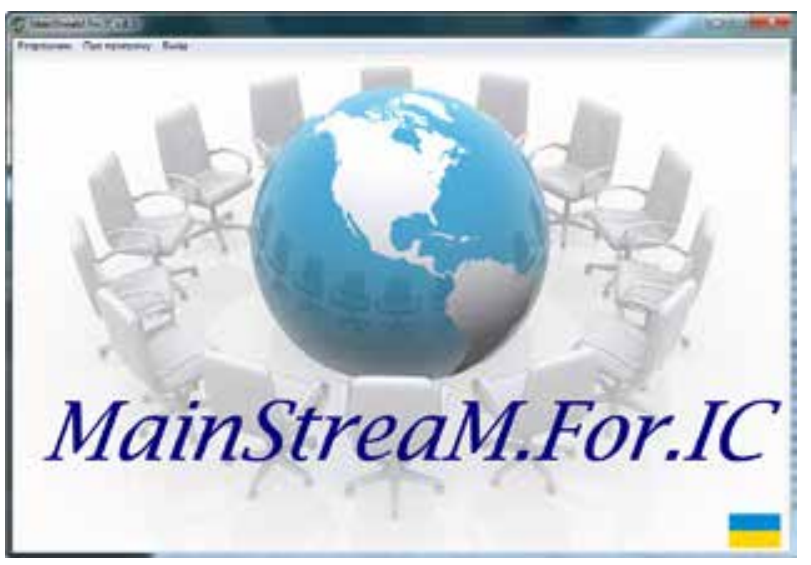

Рис. 1. Головне операційне вікно цільової комп'ютерної програми "MainStreaM.For.IC v.6.3"

виробництва сприяє інтенсифікації інноваційних процесів, моніторингу результатів реалізації нововведень, підвищенню рівня технологічної безпеки (в межах економічної) за рахунок:

1) перманентного виявлення небезпек і загроз;

2) обгрунтування доцільності трансферу;

3) обчислення витрат і масштабів зусиль на провадження процесів з адаптації промислових технологій до існуючих у національному господарстві умов функціонування;

4) підвищення швидкості і якості прийнятих управлінських рішень на основі більш достовірного й адекватного обліку параметрів зміни тенденцій розвитку виробничо-економічних і соціально-економічних систем.

Автори довели, що на активізацію діяльності у напрямі модернізації національного господарства впливають темпи розвитку і впровадження інформаційних технологій, а також оновлення їх інструментального вирішення. За особливостями впливу еволюції інформаційно-методичного забезпечення на технологічне оновлення реального сектору можна виокремити групу попередніх оригінальних розробок, що вирізняє “MainStreaM.For.IC v.6.3” серед інших програм:

1) "MainStreaM.For.IC v.4.3" - програма для визначення i обгрунтування проведення заходів із визначення змін параметрів розвиненості інтелектуального капіталу за рахунок автоматизації технологічних процесів;

2) “MainStreaM.For.IC v.5.3” - програмний продукт, який встановлює ймовірності зміни в кількісному значенні інтелектуального капіталу, що будується за результатами врахування вияву проривних процесів, які дозволяють перейти до нових вимог і правил оцінювання та прогнозування ефективності функціонування галузей, промисловості та національного господарства;

3) “MainStreaM.For.IC v.6.3" є результатом системного подання даних і виокремлення нових прин- ципів цільового інформаційного забезпечення, наукового обгрунтування доцільності реалізації інноваційних проектів і політики формування інтелектуального капіталу національного господарства.

Використання останньої доводить, що досліджуються коеволюційні процеси у контексті зміни трактування бази модернізаційних знань в межах розвитку соціального капіталу, які враховують трансформації нематеріального капіталу за рахунок:

1) впровадження досягнутих переваг щодо створення відповідних організаційних структур управління та генерування у певних галузях «проривних» рішень стосовно вдосконалення механізмів формування й досягнення визначених орієнтирів;

2) поширення досвіду використання адекватних реальним процесам методів, методик та практичного інструментарію;

3) визначення об'єктів концентрації зусиль для вдосконалення та адаптації нововведень 3 урахуванням вимог до енергоефективності, екологічної рівноваги та алярмової результативності інвестиційного забезпечення.

При цьому в архітектуру пакету "MainStreaM. For.IC v.6.3” включено моделі, побудовані на нейромережах опосередкованої взаємодії, які розташовані у часовій площині (враховують стан об'єкта дослідження як в ретроспективному, так і на сучасному історичному етапі розвитку). Це дає змогу отримати об'єктивні прогнозні значення не лише макроекономічних показників із ймовірністю до 86-90\% на основі реалізації процедур із модифікації кореляційних залежностей «прогресивні технології - національне господарство», а й обчислити оціночні та прогнозні параметри усіх складників стратегічного потенціалу (рис. 2, рис. 3).

Зазначене уможливлює визначення мінімально й максимально можливих меж зміни в параметрах інтелектуального капіталу. Зауважимо, що сучасне покоління інтелектуальної інформаційної системи, до якої віднесено й цільовий пакет “MainStreaM.For.IC v.6.3” зі штучними нейромережевими блоками, дозволяє провести визначення траєкторій розвитку за чіткими правилами, виразно спрощуючи масив вхідної інформації відповідно до обчислених показників і значень важливості зв'язків.

Це дозволяє вирішувати проблеми класифікації та ранжування інформаційної бази даних, прогнозування й оптимізації процедури формування інтелектуального капіталу для визначення складу адаптивних технологій управління та регулювання економікою. Стандартний пакет Neuro Pro 0,25, який введено до складу алгоритмічного модуля MainPro, забезпечує урахування важливості різноспрямованих деструктивних факторів впливу на розвиток стратегічного ресурсу модернізації національного господарства. 


\section{КОМП’ЮТЕРНІ НАУКИ ТА ІНФОРМАЦІЙНІ ТЕХНОЛОГІЇ № 4 2020}

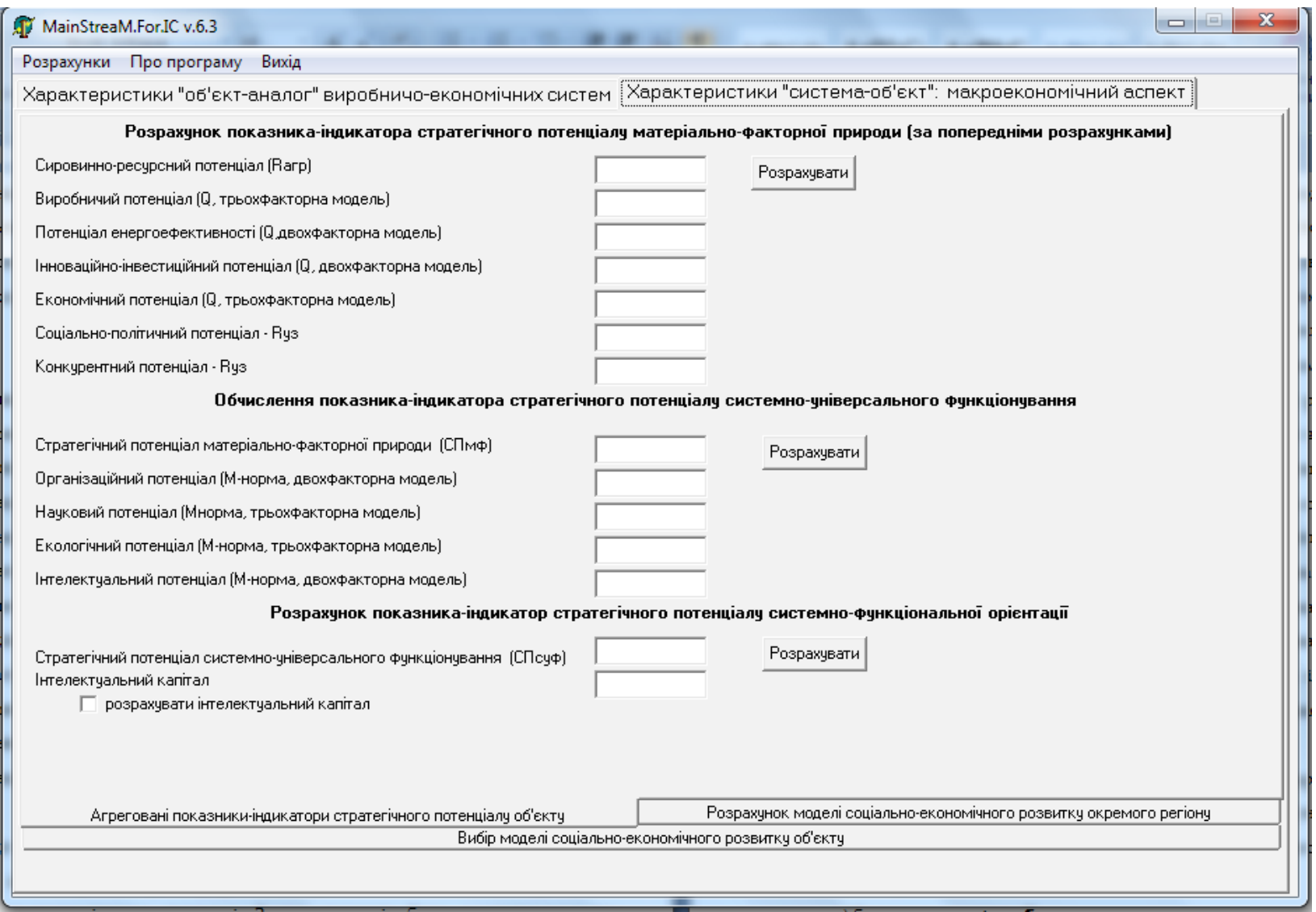

Рис. 2. Архітектура програмного забезпечення для обчислення масштабів розвиненості усіх компонентів стратегічного потенціалу національного господарства

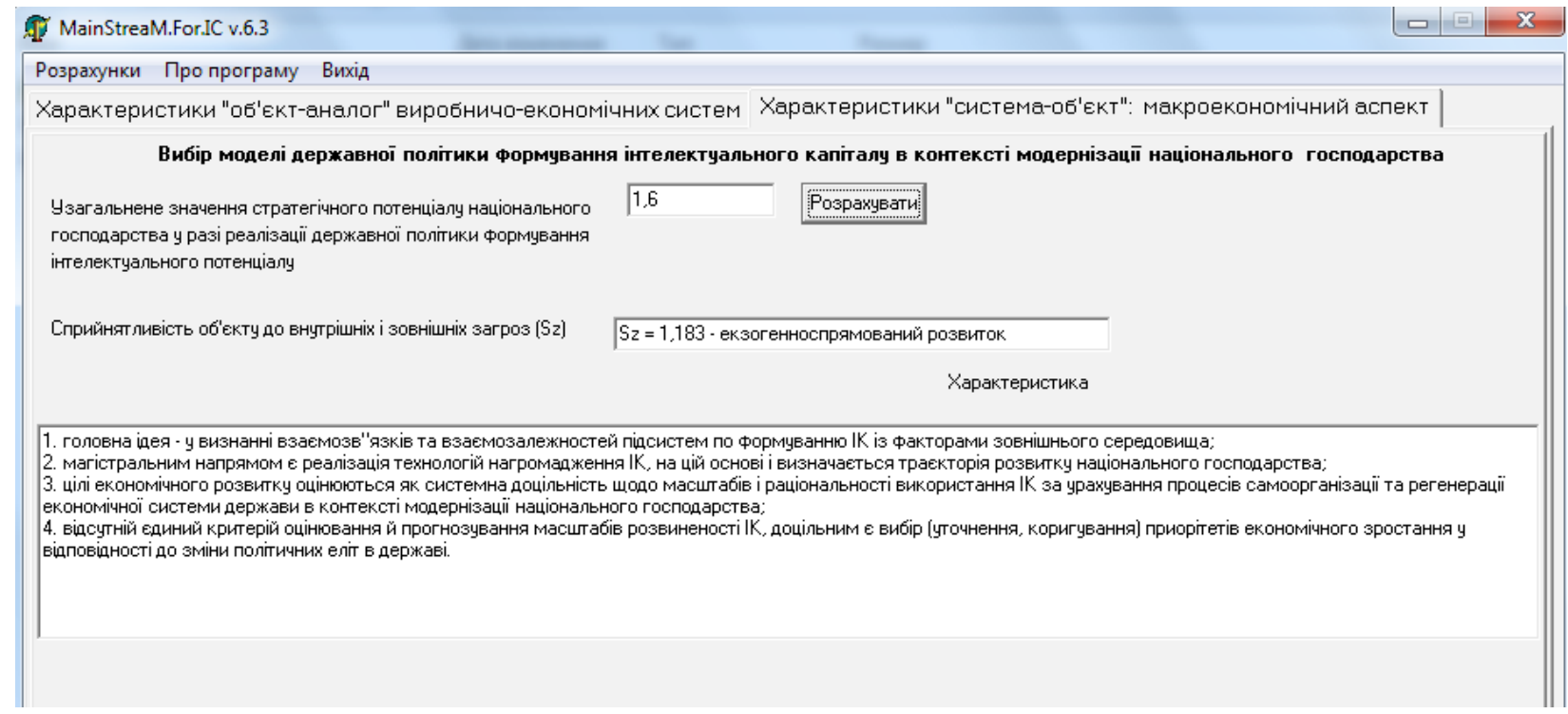

Рис.3. Модуль для обгрунтування об’єктів локалізаціїзусиль для розробки державної політики формування інтелектуального капіталу національного господарства

Проте для подальшого опису, викладу та доведення обгрунтування достовірності даних, отриманих в межах дослідження, прогнозно-аналітичних розрахунків і розробленої стратегії формування інтелекту- ального капіталу національного господарства доцільним є узагальнення дефініцій, основних понять і термінів, які використовуються у цільовому програмному забезпеченні “MainStreaM.For.IC v.6.3”. 
3 огляду на окреслені вище позиції можна констатувати, що інтелектуальний капітал національного господарства набуває форми авансованої вартості у процесі провадження господарської діяльності, коли він створюється, використовується чи реалізується певним суб'єктом господарювання (підприємством, галуззю, промисловістю чи національною економікою загалом). Щоб зрозуміти, як можна сформувати надлишок над авансованим капіталом, необхідно проаналізувати сукупність процесів, які мають місце при створенні інтелектуального продукту, сприймаючи це як результат свідомих дій підприємця (власника, інвестора).
У сучасних умовах господарської діяльності суб'єкт господарювання для створення інтелектуального продукту авансує кошти (інтелектуальні чи інші інвестиції) для придбання (використання) необхідних факторів виробництва, тобто найважливіших елементів постійного та змінного капіталу. Інтелектуальний капітал (чи інвестиції) у цьому випадку слугує виробничим капіталом, функцією якого є створення чи генерування інтелектуального продукту і додаткової вартості. Для одержання вартості та додаткової вартості у грошовій формі необхідно реалізувати інтелектуальний продукт капіталу. При цьому останній набуває форми товарного капіталу, головною функ-

Таблиця 1. Дефініційне визначення та функціональний зміст основних категорій за компонентами в цільовому пакеті програмного забезпечення*

\begin{tabular}{|c|c|}
\hline $\begin{array}{l}\text { Використовуваний } \\
\text { термін }\end{array}$ & Функціональне визначення поняття \\
\hline Алгоритмічний блок & $\begin{array}{c}\text { основна алгоритмічна одиниця інструментальної системи “MainStreaM.For.IC v.6.3”- вузол, } \\
\text { який у цільовому програмному забезпеченні виконує комплекс функцій за визначеними } \\
\text { процедурними алгоритмами; }\end{array}$ \\
\hline Алгоритмічний модуль & $\begin{array}{c}\text { алгоритмічна одиниця в межах оригінальної інструментальної системи, тобто окремий } \\
\text { вузол, який виконує в цільовому комплексі програмного забезпечення певну функцію } \\
\text { відповідно до поставленого в досліджені завдання щодо формування інтелектуального } \\
\text { капіталу; } \\
\end{array}$ \\
\hline $\begin{array}{c}\text { Первинний } \\
\text { функціональний модуль }\end{array}$ & $\begin{array}{c}\text { алгоритмічна одиниця, яка виконує одну елементарну функцію, наприклад оцінку або } \\
\text { прогноз певного показника чи параметру за окремими моделями. При цьому користувач } \\
\text { “MainStreaM.For.IC v.6.3” не має можливості змінювати функції та по-новому формалізувати } \\
\text { рішення в такому блоці; }\end{array}$ \\
\hline $\begin{array}{c}\text { Комплексний } \\
\text { функціональний модуль }\end{array}$ & $\begin{array}{l}\text { алгоритмічна одиниця, яка у проекті представляє певне програмне забезпечення, сформоване } \\
\text { iз кількох первинних функціональних модулів за алгоритмом одного з етапів прогнозу: } \\
\text { 1) стохастичного у компоненті Neuro Pro 0,25; 2) економіко-статистичного (реалізовано } \\
\text { аналіз і прогноз в компонентах MainPro та MaiGraf); 3) економіко-технологічного (здійснено } \\
\text { аналіз і прогноз в компонентах MainErgy v. 5.1 і MainProjet v.3); }\end{array}$ \\
\hline Параметр & $\begin{array}{c}\text { певна перемінна, призначена для внесення вручну обмеженої кількості інформації / } \\
\text { показників або для відображення на дисплеї результатів моделювання. Використовувані } \\
\text { параметри є динамічними. Останні зберігаютьяя в незалежній пам’яті «історії запитів» } \\
\text { програми “MainStreaM.For.IC v.6.3” }\end{array}$ \\
\hline $\begin{array}{c}\text { Комплексний } \\
\text { функціональний блок }\end{array}$ & $\begin{array}{c}\text { основна алгоритмічна одиниця, яка складається із сукупності комплексних функціональних } \\
\text { модулів, тобто з відповідним програмним забезпеченням (обчислення за стохастичною } \\
\text { фазою чи економіко-статистичною тощо). Комплексні функціональні блоки реалізують } \\
\text { певні типові функції оцінювання-прогнозування на різних концептуальних засадах і } \\
\text { за відповідними методичними підходами. Окремо блоки можна використовувати для } \\
\text { укрупненого аналізу параметрів розвиненості інтелектуального капіталу або застосовувати } \\
\text { для обгрунтування пріоритетів чи управлінського рішення; } \\
\end{array}$ \\
\hline Список & $\begin{array}{c}\text { сукупність результативних (вихідних) параметрів, об’єднаних чи згрупованих за якоюсь } \\
\text { ознакою; }\end{array}$ \\
\hline Перемінна & $\begin{array}{c}\text { алгоритмічна одиниця, яка в алгоритмах оцінювання-прогнозування представляє деяку } \\
\text { величину - інтегральну чи агреговану. Перемінні величини у програмі “MainStreaM.For.IC } \\
\text { v.6.3” класифікуються за типом і напрямом застосування; }\end{array}$ \\
\hline $\begin{array}{l}\text { Послідовні параметри } \\
\text { (bool) }\end{array}$ & $\begin{array}{c}\text { дані, які є логічними чи пов'язаними із базовою похідною величини. Вони можуть набувати } \\
\text { як значення true (true), так i false (false); }\end{array}$ \\
\hline Повні параметри (int) & числові цілі, дані; \\
\hline Чac (time) & значення часу в двоїчно-десятковому форматі (викладеному у такій формі: чч:мм); \\
\hline Вхідні параметри & інформація чи показники, які надходять / вносяться в алгоритмічний блок; \\
\hline Вихідні параметри & $\begin{array}{c}\text { інформація, показники чи база даних, які є результатом обчислення, виданим за результатами } \\
\text { функціонування алгоритмічних блоків. }\end{array}$ \\
\hline
\end{tabular}




\section{КОМП'ЮТЕРНІ НАУКИ ТА ІНФОРМАЦІЙНІ ТЕХНОЛОГІЇ № 4ロ 2020}

цією якого є реалізація інтелектуального продукту й одержання додаткової вартості у грошовій формі.

Загалом інтелектуальний продукт проходить такі стадії капіталу: грошова, виробнича і товарна. Такий послідовний рух можна визначити як кругообіг інтелектуального капіталу національного господарства. Інтелектуальний капітал у чистому вигляді можна формалізувати як математичні формули, сприйнятливі для застосування у системі національних рахунків. Зазначимо, що інтелектуальний капітал (далі - IК) - це створений або придбаний інтелектуальний продукт, який має вартісну оцінку, об'єктивований та ідентифікований (відокремлений від підприємства), утримується суб'єктом господарювання 3 метою ймовірного одержання прибутку (додаткової вартості).

Можна формалізувати модель вартісної оцінки інтелектуального капіталу, яка буде складатися із таких вартостей:

1) інтелектуального продукту (товару), створеного за умов застосування найманої праці, що визначається як сума постійного, змінного капіталу та додаткової вартості (формула (1) до інтелектуальної власності):

$$
U_{I I}=\sum C_{\text {cons }} k+\sum I n_{\text {cons }} k+\sum A d d_{\text {cost }},
$$

2) інтелектуальної власності. Це інтелектуальний капітал, об'єктивований та ідентифікований з позиції створеного, розробленого (придбаного) інтелектуального продукту, який набув права інтелектуальної власності ( $\left.U_{I K \bullet I B}\right)$;

3) ринкової власності інтелектуального потенціалу національного господарства (існуючі резерви національного господарства щодо підвищення наукоємності, ймовірні до використання ресурси різної природи і стратегічні можливості) ( $\left.U_{I К \bullet I I ~}\right)$.

Зауважимо, що комерціалізація інтелектуальної власності виникає лише за використання у національному господарстві результатів інтелектуальної діяльності на умовах укладання договорів, наприклад, між:

1) співавторами патенту;

2) власниками патенту й авторами у зв'язку 3 виплатою винагороди за використання об'єкта промислової власності;

3) власниками патенту під час комерційної реалізації інтелектуального продукту тощо.

Тому оцінювання-прогнозування масштабів розвиненості інтелектуального капіталу в контексті модернізації національного господарства зумовлює виконання пріоритетного завдання - визначення параметрів ефективності використання інтелектуального капіталу національного господарства в контексті модернізації останнього (за допомогою формули, формалізованої авторами до вигляду (2):

$$
E_{I K}=\frac{U_{I I I}+U_{I K \bullet I B}+U_{I K \bullet I I I}}{U_{I \bullet I K}+U_{I \bullet C Y P}+U_{I \bullet I K \bullet \Pi C У \Phi}+U_{B}},
$$

де $E_{I K}$-ефективність використання інтелектуального капіталу,
$U_{\text {I•IK }}-$ інвестиції в інтелектуальний капітал,

$U_{\text {I•сур }}-$ інвестиції в систему управління розвитком національного господарства;

$U_{\text {I•IК•Псуф }}$ - інвестиції в потенціали системноуніверсального функціонування, до складу яких, за свідченням дослідників [9], включені такі елементні потенціали: інноваційний, організаційний, управлінський, інформаційно-методичний, інтелектуальний); $U_{5}$ - виплати по боргових зобов'язаннях, пов'язаних із погашенням відсотків за кредитами на розвиток освіти, інтелектуальної сфери та інноваційної системи держави.

\section{ОБГОВОРЕННЯ ОТРИМАНИХ РЕЗУЛЬТАТІВ}

За результатами прогнозно-аналітичної оцінки основних макроекономічних показників і ресурсного забезпечення науково-технічного прогресу у державі встановлено складність сучасного історичного етапу розвитку національної економіки. Вона полягає у відсутності адекватного реальним соціально-економічним процесам ресурсно-функціонального забезпечення когнітивно-інформаційних аспектів руху в умовах трансляції негативного резонансу подій, зумовлених синхронним перебігом і матеріалізацією негативних економічних явищ, а саме:

1) інерційно-деструктивного впливу суб'єктів державного управління на системоутворюючі регулятори національної економіки;

2) деформації загальної системи стратегічного управління процесами формування, нарощення та раціонального й ефективного використання існуючого інтелектуального потенціалу;

3) перманентного пошуку та зміни економічних пріоритетів за відсутності визначених відповідно до національних інтересів цільових функціоналів, які пов'язують цілі із засобами їх досягнення.

3'ясовано закономірності інтелектуально-інформаційної сфери національного господарства, вивчено тенденції іiї трансформаційного впливу на темпи модернізаційних процесів у державі та можливості формування умов (і обсягів докладання зусиль) для застосування зазначеного ресурсу в розбудові моделі інноваційного розвитку України.

\section{ВИСНОВКИ}

Таким чином, обгрунтована необхідність формування дієвої політики формування інтелектуального капіталу національного господарства для досягнення загальноекономічного прискорення і реалізації інноваційно спрямованої української моделі економічного зростання. Попри усі наявні соціально-економічні, суспільно-політичні загрози і ризики лише консолідація стратегічного потенціалу на засадах інтенсифікації процесів формування та нарощення інтелектуального капіталу дозволить побудувати еволюційну економіку інформаційного типу в межах демократичної правової держави для успішної реалізації національних економічних інтересів України. 


\section{REFERENCES}

[1] Baulina T.V. Formuvannia y naroshchennia intelektualnoho kapitalu na synerhetychnykh zasadakh / Baulina T.V. // Materialy Mizhnarodnoi naukovo-praktychnoi konferentsii: "Ukraina-Polshcha-YeS: suchasnyi stan ta perspektyvy". Polshcha : Opolie. 2008. S. 11-18.

[2] Baulina T.V. Intelektualnyi potentsial pidpryiemstva yak holovnyi faktor v upravlinni orhanizatsiinymy zminamy // Visnyk Khmelnytskoho natsionalnoho universytetu / Baulina T.V. / Khmelnytskyi, 2005. № 6. S. 9-13.

[3] Baulina T.V. Znachennia intelektualnykh investytsii v sotsialno-ekonomichnomu rozvytku derzhavy / Baulina T.V. // Materialy Mizhnarodnoi naukovo-praktychnoi konferentsii: "Ukraina-Chekhiia-YeS: suchasnyi stan ta perspektyvy". Praha : KhNTU i YeUMV, 2008. S. 5-12.

[4] Baulina T.V. Rol intelektualnoho kapitalu suspilstva v formuvanni ta rozvytku vysokoiakisnoho rivnia vyshchoi osvity Ukrainy / Baulina T.V. / Materialy Mizhnarodnoi naukovo-praktychnoi konferentsii: "Rozvytok osvity, vstup do Bolonskoho protsesu". K., 2007. S. 56-58.

[5] Baulina T.V. Formuvannia intehrovanoi kontseptsii upravlinnia intelektualnym kapitalom Ukrainy (Tekst) / T.V. Baulina // Problemy nauky (nauk.-pr. zh-1/ hol. red. B.A. Malitskyi). Kyiv : TsNTEI, TsDPIN im. H.M. Dobrova NANU, 2009. № 10. S. 6-11.

[6] Baulina T.V. A.S. 21673 Makroekonomichne rehuliuvannia protsesiv zabezpechennia efektyvnosti vykorystannia intelektualnoho kapitalu: metodolohiia otsinky i prohnoz, metodychni pidkhody ta praktychnyi instrumentarii A.S. 21673 Ukraina / Baulina T.V. Zaiavleno 15.05.2010. Opublikovano u biuleteni: "Ofitsiinyi biuleten avtorske pravo i sumizhne pravo". 2010. № 19. 4 s.

[7] Baulina T.V. A.S. 28673 Kompiuterna prohrama "Prohnozno-analitychna otsinka ta dobir tekhnolohii stratehichnoho upravlinnia "MainStreaM.For.Ic. v.6.3." / Baulina T.V., Mykytenko D.O., Demeshok O.O. (Ukraina) // Zaiavl. 07.04.2010. № 29220. Opublikovano u biuleteni "Ofitsiinyi biuleten avtorske pravo i sumizhne pravo", 2010. № 18. $300 \mathrm{~s}$.

[8] Baulina T.V. Realizatsiia bazovykh polozhen intehrovanoi kontseptsii formuvannia intelektualnoho kapitalu ta yoho identyfikatsiia [Tekst] / B.M. Danylyshyn, T.V. Baulina // Natsionalne hospodarstvo Ukrainy: teoriia ta praktyka upravlinnia [zb. nauk. pr. / vidp. red. L.V. Deineko]. K. : RVPS Ukrainy NAN Ukrainy, 2010. S. 231-237.

[9] Alymov O.M. Stratehichnyi potentsial - sukupni mozhlyvosti natsionalnoi ekonomiky po dosiahnenniu tsilei zbalansovanoho rozvytku / Mykytenko V.V., Alymov O.M. // Produktyvni syly Ukrainy : naukovo-teoretychnyi ekonomichnyi zhurnal. K. : RVPS Ukrainy NAN Ukrainy, 2006. № 1. S. 135-151.

\section{СПИСОК ВИКОРИСТАНОЇ ЛІТЕРАТУРИ}

[1] Бауліна Т.В. Формування й нарощення інтелектуального капіталу на синергетичних засадах / Бауліна Т.В. // Матеріали Міжнародної науково-практичної конференції: «Україна-Польща-ЄС: сучасний стан і перспективи». Польща : Ополє. 2008. С. 11-18.

[2] Бауліна Т.В. Інтелектуальний потенціал підприємства як головний фактор в управлінні організаційними змінами // Вісник Хмельницького національного університету / Бауліна Т.В. / Хмельницький, 2005. № 6. С. 9-13.

[3] Бауліна Т.В. Значення інтелектуальних інвестицій в соціально-економічному розвитку держави / Бауліна Т.В. // Матеріали Міжнародної науково-практичної конференції: «Україна-Чехія-СС: сучасний стан і перспективи». Прага : ХНТУ і ЄУМВ. 2008. С. 5-12.

[4] Бауліна Т.В. Роль інтелектуального капіталу суспільства в формуванні та розвитку високоякісного рівня вищої освіти України / Бауліна Т.В. / Матеріали Міжнародної науково-практичної конференції: «Розвиток освіти, вступ до Болонського процесу». К., 2007. С. 56-58.

[5] Бауліна Т.В. Формування інтегрованої концепції управління інтелектуальним капіталом України (Текст) / Т.В. Бауліна // Проблеми науки (наук.-пр. ж-л / гол. ред. Б.А. Маліцький). Київ : ЦНТЕІ, ЦДПІН ім. Г.М. Доброва НАНУ, 2009. № 10. С. 6-11.

[6] Бауліна Т.В. А.С. Макроекономічне регулювання процесів забезпечення ефективності використання інтелектуального капіталу: методологія оцінки і прогноз, методичні підходи та практичний інструментарій А.С. 21673 Україна / Бауліна Т.В. Заявлено 15.05.2010. Опубліковано у бюлетені: «Офіційний бюлетень авторське право і суміжне право». 2010. № 19. 4 c.

[7] Бауліна Т.В. А.С. 28673 Комп’ютерна програма «Прогнозно-аналітична оцінка та добір технологій стратегічного управління “MainStreaM.For.Ic. v.6.3.” / Бауліна Т.В., Микитенко Д.О., Демешок О.О. (Україна) // Заявл. 07.04.2010. № 29220. Опубліковано у бюлетені «Офіційний бюлетень авторське право і суміжне право», 2010. № 18. 300 с.

[8] Бауліна Т.В. Реалізація базових положень інтегрованої концепції формування інтелектуального капіталу та його ідентифікація [Текст] / Б.М. Данилишин, Т.В. Бауліна // Національне господарство України: теорія та практика управління [зб. наук. пр. / відп. ред. Л.В. Дейнеко]. К. : РВПС України НАН України, 2010. С. 231-237.

[9] Алимов О.М. Стратегічний потенціал - сукупні можливості національної економіки по досягненню цілей збалансованого розвитку / Микитенко В.В., Алимов О.М. // Продуктивні сили України : науково-теоретичний економічний журнал. К. : РВПС України НАН України, 2006. № 1. С. 135-151. 